\title{
Exploring Exposure and Symptomatic Differences of Chikungunya Virus in the Adult Population of Grenada
}

\author{
SL Busch, S Bidaisee
}

\begin{abstract}
Objective: From December 2013 to March 7, 2015, a total of 22283 confirmed/probable cases and 863 207 suspected cases of chikungunya were reported in the Caribbean (1). More information regarding symptoms and protection factors is necessary to accurately inform the public and have effective case management. The purpose of this study was to assess age group differences with respect to chikungunya $(C H I K V)$ symptoms and explore protection differences of people who have and have not had CHIKV.

Methods: A cross-sectional study sampling 154 participants was conducted from April to May 2015. Participants completed a 37-item questionnaire and were recruited from public places and at a local retirement association in Grenada.

Results: Knee joint pain $(p<0.05$ ) and persisting symptoms (rash $\mathrm{p}<0.05$, muscle pain $\mathrm{p}<0.005$, ankle joint pain, $\mathrm{p}<0.05)$ were statistically significant for all age groups. No statistical difference was found for taking precautions before and after the outbreak for those who did and did not have CHIKV. However, precaution comparisons for the home $(\mathrm{p}<0.001)$ and work $(\mathrm{p}<0.001)$ environments showed significant non-change before and after the outbreak.

Conclusion: This study found that age was a factor for symptom development and persistence, and resistance to behaviour change is an important factor for future epidemic responses and intervention studies.
\end{abstract}

Keywords: Arboviral outbreak, Caribbean disease outbreak, chikungunya virus, emerging infectious disease

\section{Explorando la Exposición al Virus Chikunguña y sus Diferencias Sintomáticas en la Población Adulta de Granada}

\author{
SL Busch, S Bidaisee
}

\begin{abstract}
RESUMEN
Objetivo: De diciembre de 2013 al marzo 7 de 2015, un total de 22,283 casos probables/confirmados, y 863,207 casos sospechosos fueron reportados en el Caribe (1). Se requiere más información sobre los sintomas y factores de protección para informar al público con exactitud y lograr un manejo eficaz de los casos. El propósito de este estudio fue evaluar las diferencias de los grupos por edad con respecto a los sintomas de la fiebre chikunguña (CHIKV) y explorar las diferencias de protección entre las personas que han tenido y no han tenido CHIKV.

Métodos: Un estudio transversal qué tomó 154 participantes como muestras, se realizó de abril a mayo de 2015. Los participantes completaron un cuestionario de 37 items y fueron reclutados de lugares públicos y una asociación local de retiro en Granada.

Resultados: El dolor en las articulaciones de la rodilla $(\mathrm{p}<0.05)$ y los sintomas persistentes (erupción $\mathrm{p}<0.05$, dolor muscular $\mathrm{p}<0.005$, dolor en las articulaciones tobillo, $\mathrm{p}<0.05)$ fueron esta-dísticamente significativos para todas las edades. No se encontró ninguna diferencia estadistica significativa en cuanto a tomar precauciones antes y después del brote, tanto para aquellos que tuvieron como para los que no tuvieron CHIKV. Sin embargo, las comparaciones de precaución con respecto al hogar $(p<0.001)$ y el entorno de trabajo $(\mathrm{p}<0.001)$ mostraron una significativa ausencia de cambios antes y después del brote.
\end{abstract}

From: Department of Public Health and Preventive Medicine, School of Medicine, University Centre, St George's University, Grenada.
Correspondence: Dr S Bidaisee, Department of Public Health and Preventive Medicine, School of Medicine, University Centre, St George's University, Grenada, W.I. Email: sbidaisee@sgu.edu 
Conclusión: Este estudio encontró que la edad fue un factor para el desarrollo y persistencia de sintomas, y la resistencia al cambio de comportamiento es un factor importante para futuras respuestas epidémicas y estudios de intervención.

Palabras claves: Brote arboviral, brote de la enfermedad del Caribe, virus chikunguña, enfermedad infecciosa emergente

West Indian Med J 2017; 66 (1): 21

\section{INTRODUCTION}

Chikungunya virus (CHIKV) has become an increasingly burdensome infectious disease that continues to spread globally. Transmitted by mosquitoes of the species $A$ aegypti and $A$ albopictus, the disease has affected over sixty countries as of May 2015 (1-3). Historic outbreaks have occurred in Africa and Asia, with recent outbreaks throughout the Americas and Europe (1). The first recorded outbreak of this ribonucleic acid virus dates back to 1952 in southern Tanzania, Africa (2-4).

December 2013 marked the introduction and first documented local transmission of CHIKV in the Caribbean $(5,6)$. Specifically, Grenada experienced its first case in late June 2014, and as of March 7, 2015 had experienced 26 confirmed/probable cases and 3070 suspected cases (1). Like the majority of the Caribbean region, these data are misleading due to physician misdiagnosis, as CHIKV presents similarly with other infections like dengue fever, leptospirosis and some rheumatologic infections (7).

Symptoms generally develop within three to seven days after exposure and can include fever, joint pain, headache, muscle pain, joint swelling and rash (8-10). Infection is not typically accompanied by serious complications and rarely results in death, with most individuals fully recovering in seven to ten days $(9,11)$. However, older adults are at a higher-risk of developing a severe CHIKV infection which is characterized by increased overall length of infection and persisting symptoms $(11,12)$. Although no formal treatment is available, after initial infection, a person is usually protected against future infections $(11,12)$.

Previous research analysing CHIKV symptoms has focussed on the large, 2005-06 Réunion Island epidemic. One study found the majority of pain experienced from CHIKV was located mostly in the upper and lower limbs and less frequently in the neck and back. Quality of life, instead of participant age or duration of pain, affected pain intensity (13). A longitudinal study on Reunion Island followed patients still experiencing arthralgia (joint pain) three years after their initial CHIKV onset and found patients older than 35 years were more likely to experience chronic arthralgia compared to those younger than 35 years (14). Independent research studying arthralgia in the older teenager and adult population showed similar findings with roughly $64 \%$ of participants experiencing chronic arthralgia 18 months after infection (15). Researchers posit that persistent arthralgia for at least four months after initial onset is a risk factor for chronic arthralgia (14).
With much research focussing on the effects of arthralgia, a need exists for age group specific symptoms and mosquito protection differences to be examined. With new outbreaks occurring, CHIKV's endemicity continues to spread to new regions. As an understudied virus, this research provides more information regarding symptoms and protection factors to help inform more effective case management in Grenada and the Caribbean. The purpose of this study is to assess age group differences with respect to CHIKV symptoms and explore protection differences of people who have and have not had CHIKV.

\section{SUBJECTS AND METHODS}

This study was reviewed and approved by St George's University (SGU), Institutional Review Board (IRB). As an introductory study with limited time and available data, primary data collection for this cross-sectional study occurred in April and May 2015. One hundred and fifty-four Grenada residents aged 18 years and older were conveniently sampled. Participants included those who resided in Grenada for at least the past 10 months and excluded those who were non-Caribbean students at SGU. The population was divided into the following age categories to ensure adequate age group representation: $18-29$ years, $30-49$ years, $50-64$ years and 65 years and older.

A 37-item paper based, questionnaire was developed to assess the objectives. The questionnaire had four main sections: eight demographic questions, 14 symptom questions, nine home environment questions and six Occupation environment questions. Home environment was defined as the external open atmosphere that surrounds the place a person permanently resides. Occupation environment was defined as the geographic location or atmosphere of a person's primary job that acts as the main source of revenue. The questionnaire was pilot tested for reliability with participants who were representative of the target population. Participants from public locations and a local retirement association in St George were approached by the Primary Investigator (PI) and asked to participate in the study. The questionnaire was anonymous, took roughly 15 minutes to complete and was returned to an envelope. If the participants could not read or write, the questionnaire was read to them by the PI and the answers were recorded.

Data were entered into Epi Info, analysed using SPSS 22 and data cleaning included checking for errors and missing 
data. Frequencies and percentages for categorical variables were computed. A $p<0.005$ was statistically significant for test.

\section{RESULTS}

Demographics

From the 165 questionnaires, 11 did not meet the inclusion criteria leaving a sample size of 154 (93.3\%). After data collection, participants were stratified according to four age groups: $18-29$ years $(63.2 \%$ females, $\mathrm{n}=24), 30-49$ years $(65.9 \%$ females, $\mathrm{n}=27)$, 50-64 years $(52.5 \%$ females, $\mathrm{n}=21)$ and $65^{+}$ years $(63.6 \%$ males, $\mathrm{n}=21)$. Roughly $56 \%$ of the sample was females and over $80 \%$ of participants were lifelong inhabitants of Grenada. Over $50 \%$ of participants had not completed education past secondary school and over $20 \%$ worked in sales. Roughly equal proportions of participants stated they had experienced CHIKV (72.7\%) and had someone living with them who experienced CHIKV (73.4\%), which was found to be significant $(p<0.005,80.4 \%, \mathrm{n}=90)$. Most participants lived $(78.6 \%)$ and worked $(62.3 \%)$ in St George.

\section{Symptoms}

All 112 participants (58.9\% female) who reported having CHIKV were stratified by age group: $18-29$ years $(21.6 \%)$, $30-49$ years $(29.7 \%), 50-64$ years $(26.1 \%)$ and $65^{+}$years $(22.5 \%)$. Table 1 shows that knee joint pain was statistically significant for overall age group $(p<0.05, \mathrm{n}=73)$ and the 30 49 years age group experienced the greatest number of symptoms. Knee joint pain severity was assessed on a condensed Likert scale $(1,3,5)$, with five being the most severe and was also significant $(p<0.05, \mathrm{n}=73)$.

Table 1: Frequency of chikungunya symptoms per age group, sample size $\mathrm{n}=112$

\begin{tabular}{lcccrc}
\hline Symptom & $\mathbf{1 8 - 2 9}$ & $\mathbf{3 0 - 4 9}$ & $\mathbf{5 0 - 6 4}$ & $\mathbf{6 5}^{+}$ & Total \\
\hline Headache & 18 & 25 & 18 & 9 & 70 \\
Fever & 20 & 28 & 19 & 13 & 80 \\
Rash & 16 & 19 & 9 & 5 & 49 \\
Joint swelling & 16 & 21 & 9 & 6 & 52 \\
Muscle pain & 20 & 23 & 10 & 4 & 57 \\
Joint pain: Knees & 18 & 22 & 17 & 16 & $73 *$ \\
Joint pain: Wrists & 16 & 21 & 16 & 11 & 64 \\
Joint pain: Back & 12 & 16 & 10 & 7 & 45 \\
Joint pain: Ankles & 17 & 22 & 16 & 8 & 63 \\
Joint pain: Neck & 11 & 14 & 9 & 4 & 38 \\
\hline
\end{tabular}

$* p<0.05$

The majority of participants in all age groups rated knee joint pain as most severe, and the $65^{+}$age group reported the least amount of knee pain overall. Almost 50\% $(44.1 \%, \mathrm{n}=$ 49) of the participants stated the majority of symptoms lasted 1-4 days, with symptom duration progressively decreasing over time. Table 2 shows rash $(p<0.05)$, muscle pain $(p<$ $0.005)$ and ankle joint pain $(p<0.05)$ were statistically significant as non-persisting symptoms for age group overall. Rash $(p<0.05)$, muscle pain $(p<0.005)$ and joint pain in the knees $(p<0.001)$, wrists $(p<0.001)$ and ankles $(p<0.001)$ were also significant as non-persisting symptoms for participants who encountered persisting symptoms.

Table 2: Distribution of persisting symptoms by age group, sample size $\mathrm{n}=111$

Persisting symptom: No \% (n)

\begin{tabular}{cccc}
\hline Age group & Rash & Muscle pain & Joint pain: Ankles \\
\hline $18-29$ & $70.8(17)$ & $62.5(15)$ & $70.8(17)$ \\
$30-49$ & $90.9(30)$ & $81.8(27)$ & $63.6(21)$ \\
$50-64$ & $96.6(28)$ & $93.1(27)$ & $69.0(20)$ \\
$65^{+}$ & $92.0(23)$ & $100.0(25)$ & $96.0(24)$ \\
\hline$p$-value & $<0.05$ & $<0.005$ & $<0.05$ \\
\hline
\end{tabular}

\section{Mosquito protection}

Chikungunya precautions were assessed in the home and occupation environment. Roughly $66 \%$ of participants reported spending $60 \%$ to $80 \%(n=150)$ of their day outside. About $44.1 \%$ of those who had CHIKV spent $80 \%$ to $100 \%(n=150)$ of their day outside and almost $85 \%(\mathrm{n}=151)$ did not use body mosquito repellant. For those participants who took precautions at home $(85 \%, \mathrm{n}=152)$, bed-nets $(p<0.05)$, mosquito screens $(p<0.001)$ and mosquito coils $(p<0.005)$ were significant for nonuse and sprays $(p<0.001)$ were significant for use (Table 3).

Table 3: Taking precautions against mosquitoes at home, sample size $\mathrm{n}=152$

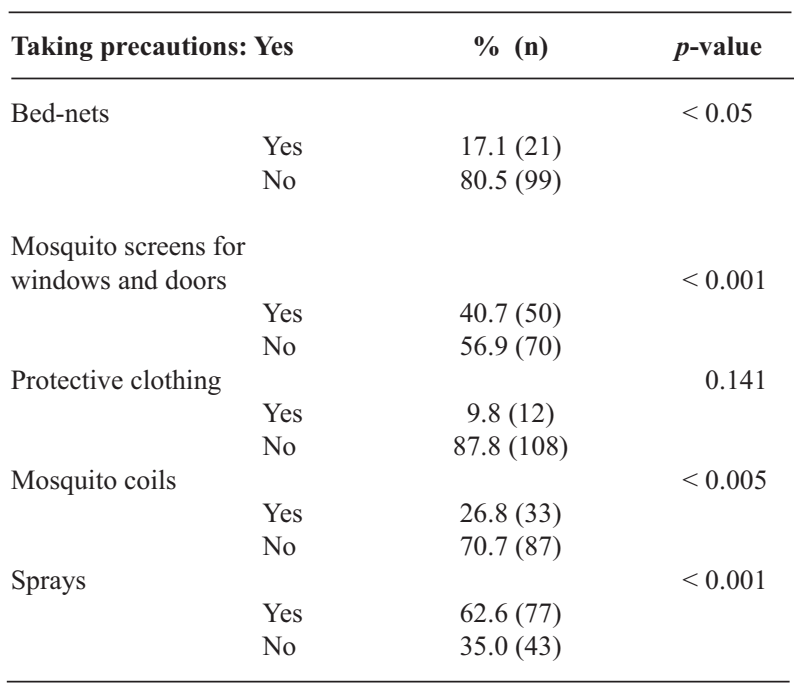

Table 4 compares mosquito precautions taken before to after the Chikungunya outbreak and shows all precaution types used before were significant $(p<0.001)$ for also being used after the outbreak. No statistical associations were found when analysing CHIKV status with precautions taken at home when measuring, independently, before and after the outbreak.

Roughly $70 \%$ of females and $81 \%$ of males did not take mosquito precautions at work $(\mathrm{n}=114)$. The $50-64$-year age group took the most mosquito precautions (38.2\%) while the $18-29$-year age group took the least $(\sim 85 \%, \mathrm{n}=112)$. About 
Table 4: Taking precautions against mosquitoes at home: comparing before the chikungunya outbreak to after, sample size $\mathrm{n}=150$

\begin{tabular}{lccc}
\hline \multicolumn{1}{c}{ Taking precautions before: Yes } & $\%$ (n) & $\boldsymbol{p}$-value \\
\hline Bed-nets & & & $<0.001$ \\
& Yes & $90.9(20)$ & \\
& No & $9.1(2)$ & \\
Mosquito screens for & & & \\
windows and doors & & & $<0.001$ \\
& Yes & $93.6(44)$ & \\
& No & $6.4(3)$ & \\
Protective clothing & & & $<0.001$ \\
& Yes & $77.8(7)$ & \\
& No & $22.2(2)$ & \\
Mosquito coils & & & $<0.001$ \\
& Yes & $75.8(25)$ & \\
& No & $24.2(8)$ & \\
Sprays & & & $<0.001$ \\
& Yes & $95.7(67)$ & \\
& No & $4.3(3)$ & \\
\hline
\end{tabular}

$71 \%(\mathrm{n}=114)$ of those that did not take precautions at work had CHIKV and 28.3\% $(\mathrm{n}=131)$ who had CHIKV said their work environment during that time was predominately outdoors $(p<0.001)$. A comparison of mosquito precautions taken before to after the CHIKV outbreak shows those who took precautions most of the time and those who usually did not take precautions before the outbreak were significant $(p<$ $0.001, \mathrm{n}=114$ ) for the same work behaviours after.

\section{DISCUSSION}

The first objective was to assess age group differences with respect to CHIKV symptoms. Knee joint pain and persisting symptoms were found to be significant for overall age group. Specifically, the 30-49-year age group experienced knee joint pain in the highest proportion and the $65^{+}$-year age group in the least. The majority of participants from each age group rated knee joint pain the highest severity. Plausible explanations for these findings are that older populations tend to be less mobile and as a result may not have experienced knee joint pain to the same extent and severity. The 30-49-year age group represents the working class whereas the majority of the $65^{+}$-year age group was retired. Adults in this working class represented over $30 \%$ in the occupation groups that required mostly standing, working outside or manual labour, which demands for consistent knee usage. With the knees being one of the anatomical regions highly affected by injury, previous injuries may have affected these participants. This finding is consistent with a previous study which also found that the majority of pain was located in the lower limbs (13).

Further supporting that age may be an important factor in symptom progression is that rash, muscle pain and ankle joint pain were significant as non-persisting symptoms for overall age group. The 18-29-year and 30-49-year age groups experienced these non-persisting symptoms for longer durations whereas the 50-64-year and $65^{+}$-year age groups experienced these non-persisting symptoms for shorter durations. As stated earlier, these two younger age groups represent the working class. With continual usage of muscles and joints throughout daily activities, these symptoms would persist longer than in older populations where these bodily movements are not as strenuous or persistent. Also of importance are the symptoms (rash, muscle pain and joint pain in the knees, wrists and ankles) that were found to be non-persisting symptoms for those who had persisting symptoms. Generally, rash and muscle pain are not considered long-term symptoms for many illnesses which could explain the short duration. Knee, wrist and ankle joint pain may not have been detected as a persisting symptom due to the smaller sample size of those that experienced persisting symptoms. However, this finding may be important for clinical management in future CHIKV outbreaks and therefore should be further explored.

The second objective was to explore protection differences for people who have and have not had CHIKV. No significant differences for precautions taken before and after the outbreak were found. However, bed-nets, mosquito screens, and mosquito coils were significant for non-use and sprays were significant for use for participants taking precautions in the home environment. This finding can be explained by preference, cheaper cost and availability of products in Grenada. With the socio-economic status of Grenada, sprays may be more practical and economical as they are less expensive than purchasing and installing window and door screens. Additionally, the infrastructure of homes and businesses in Grenada may not be equipped for screens thus, not being a viable option. With many products being imported to Grenada, screens, bed-nets and mosquito coils may be less available. Furthermore, precaution comparisons for before and after the CHIKV outbreak for the home environment found that precautions taken before were significant for also being taken after. This is expected as humans are habitual in nature and reiterates the resistance to making behaviour changes. This lack of behaviour change was also found for before and after comparisons in the work environment. These are positive findings as there was not a reduction in the precautions taken after the CHIKV outbreak. This observation of stagnant human behaviour is not new or uncommon, given the widely studied behaviour change theories. Nonetheless, behaviour change should be considered when informing future mosquito protection studies so that effective interventions can be established.

This study collected baseline data which added to the currently limited literature. The questionnaire was reliable and valid, and the data collection process was standardized. However, cross-sectional design does not allow for causation to be established. Bias may include selection bias, self-reporting inaccuracies, recall bias and non-response bias. Additionally, the sample is not representative of the population, limiting the study's generalizability. 
In conclusion, knee joint pain and persisting symptoms were statistically significant for the overall age groups. No statistical difference was found for taking precautions before and after the outbreak for those who did and did not have CHIKV. However, precaution comparisons for the home and work environments showed significant non-change for before and after the outbreak. This study supports the idea that age may be a factor for symptom development and persistence. Further research should be conducted to assess age group specific symptoms in terms of duration, severity and symptom type to better inform healthcare providers and to increase general public knowledge. This study also emphasizes the resistance to behaviour change which is important for future epidemic responses and intervention studies.

\section{ACKNOWLEDGEMENTS}

I would like to thank Dr Hegamin-Younger for her dedication, knowledge and guidance in this research project. I would also like to thank the participating of the study.

\section{REFERENCES}

1. Caribbean Public Health Agency. CARPHA'S interim guidelines [Internet]. Port of Spain, Trinidad and Tobago: CARPHA; July 2011 [rev. March 2015; cited March 2015]. Available from: http://carpha.org/What-WeDo/Public-Health-Activities/Chikungunya

2. World Health Organization. Chikungunya [Internet]. WHO; [n.d] [rev. May 2015; cited 24 Jan 2015]. Available from: http://www.who.int/mediacentre/factsheets/fs327/en/.

3. Burt FJ, Rolph MS, Rulli NE, Mahalingam S, Heise MT. Chikungunya: a re-emerging virus. Lancet 2012; 379: 662-71.

4. Robinson MC. An epidemic of virus disease in Southern Province, Tanganyika Territory, in 1952-531: Clinical features. Trans R Soc Trop Med Hyg 1955; 49: 28.

5. Cauchemez S, Ledrans M, Poletto C, Quenel P, de Valk H, Colizza V et al. Local and regional spread of chikungunya fever in the Americas. Euro Surveill 2014; 19: 20854.
6. Centers for Disease Control and Prevention. Chikungunya in the Caribbean [Internet]. Atlanta, GA: CDC; 13 Dec 2013 [rev. 6 March 2015; cited 31 Jan 2015]. Available from: http://wwwnc.cdc.gov/travel/notices/watch/chikungunya-caribbean

7. Centers for disease control and prevention. Chikungunya virus: clinical evaluation and disease [Internet]. Atlanta, GA: CDC; [n.d] [rev. 10 Feb 2015; cited 10 March 2015]. Available from: http://www.cdc.gov/chikungunya/hc/clinicalevaluation.html

8. Gerardin P, Guernier V, Perrau J, Fianu A, Le Roux K, Grivard P et al. Estimating Chikungunya prevalence in La Reunion Island outbreak by serosurveys: two methods for two critical times of the epidemic. BMC Infect Dis 2008; 8: 99

9. Centers for disease control and prevention. Chikungunya virus: symptoms, diagnosis, and treatment [Internet]. Atlanta, GA: CDC; [n.d] [rev. 26 March 2014; cited 18 Jan 2015]. Available from: http://www. cdc.gov/chikungunya/symptoms/index.html

10. Caribbean 360: News Around the Caribbean. Grenada enforces 1952 legislation to deal with chikungunya virus [Internet]. Bridgetown, Barbados: Caribbean 360; 2 July 2014 [n.d; cited 18 Jan 2015]. Available from: http://www.caribbean360.com/news/grenada-enforces-1952-legislationto-deal-with-chikungunya-virus

11. Mayo Clinic. Infectious diseases [Internet]. Rochester, MN: Mayo Clinic; 31 July 2014. [n.d; cited 18 Jan 2015]. Available from: http://www.mayoclinic.org/diseases-conditions/infectious-diseases/expert-answers/ chikungunya-fever/faq-20109686

12. Centers for disease control and prevention. Chikungunya atypical and severe disease manifestations [Internet]. Atlanta, GA: CDC; [n.d] [rev. 7 Oct 2014; cited 10 March 2015]. Available from: http://www.cdc.gov/ chikungunya/pdfs/Chikungunya-atypical-severe-disease_Healthcareprovider-factsheet-10-07-2014.pdf

13. De Andrade DC, Jean S, Clavelou P, Dallel R, Bouhassira D. Chronic pain associated with the chikungunya fever: long lasting burden of an acute illness. BMC Infect Dis 2010; 10: 31.

14. Schilte C, Staikowsky F, Couderc T, Madec Y, Carpentier F, Kassab S et al. Chikungunya virus-associated long-term arthralgia: a 36-month prospective longitudinal study. PLoS Negl Trop Dis 2013; 7: e2137.

15. Borgherini G, Poubeau P, Jossaume A, Gouix A, Cotte L, Michault A et al. Persistent arthralgia associated with chikungunya virus: a study of 88 adult patients on reunion island. Clin Infect Dis 2008; 47: 469-75. 